\title{
IDENTIFICATION AND CULTIVATION OF MFW 23-08 ISOLATED FROM MARINE SPONGES FOR BIOACTIVE COMPOUND PRODUCTION
}

\section{Identifikasi dan Kultivasi Kapang MFW 23-08 yang Diisolasi dari Spons Laut untuk Produksi Komponen Bioaktif}

\author{
Ekowati Chasanah ${ }^{1)^{*}}$, Asri Pratitis ${ }^{1)}$, and Wibowo Mangunwardoyo ${ }^{2)}$ \\ 1) Research and Development Center for Marine and Fisheries Product Processing and Biotechnology \\ 2)Departement of Microbiology, Faculty of Mathematic and Science, University of Indonesia \\ *Correspondence Author: ekowatichasanah@gmail.com. KS. Tubun Petamburan VI Jakarta Pusat 10260.
}

\begin{abstract}
Production of marine bioactive compound for commercial usage has been hampered due to the problem of raw material supply. To overcome this, marine microbes especially those associated with the bioactive-compound producer biota, has been explored as bioactive sources, with several advantages such as shorter production time, cheaper production cost and avoiding over exploitation of marine biota sources. Previous research showed that fungi MFW 23-08 was one of the potential isolates from Wakatobi sponges which produced bioactive compounds that was active against breast cancer cell line and as antioxidant. This study was intended to identify MFW 23-08 and optimize the production of its bioactive compound through optimization of MFW 23-08 culture. Culture optimization was conducted using 3 liquid media, i.e. malt extract broth (MEB), glucose peptone yeast (GPY), and minimal fungal media (MFM), and cultivation periods, i.e. 2, 4, 6, 8, and 10 wk. Results revealed that MFW 23-08 crude extract of 2 wk-MFM cultivation, at the concentration of $30 \mu \mathrm{g} / \mathrm{ml}$, was able to retard $87 \%$ breast cancer (T47D) cell growth. While at concentration of $100 \mu \mathrm{g} / \mathrm{ml}$, the $6 \mathrm{wk}$. MEB cultivated extract was able to hamper free radicals $(56 \%)$. However, the crude extract from MFM media cultivation, in the concentration of 50 and $100 \mu \mathrm{g} / \mathrm{ml}$ was not able to inhibit Escherichia coli and Staphylococcus aureus growth. Based on molecular identification using ITS1-ITS4 primers, MFW 23-08 isolate was 99\% similar to Penicillium citrinum, $P$. griseofolvum and Penicillium sp.
\end{abstract}

Keywords: bioactive, fungi, sponge, MFW 23-08, breast cancer cell

\begin{abstract}
ABSTRAK
Produksi komponen bioaktif dari laut secara komersial dibatasi oleh permasalahan pasokan bahan baku. Untuk mengatasi hal ini, mikroba terutama yang berasosiasi dengan biota laut penghasil senyawa aktif telah dieksplorasi sebagai sumber senyawa aktif, dengan beberapa keuntungan seperti waktu produksi yang menjadi lebih pendek, produksi dengan biaya lebih rendah dan menghindari eksploitasi berlebih terhadap biota sumber senyawa bioaktif laut. Penelitian terdahulu menghasilkan kapang MFW 23-08 sebagai salah satu kapang yang berpotensi menghasilkan senyawa bioaktif antikanker payudara dan sebagai sumber antioksidan Penelitian ini bertujuan untuk melakukan identifikasi MFW 23-08 dan optimasi produksi senyawa bioaktif yang dihasilkan oleh kapang MFW 23-08. Optimasi kultivasi dilakukan dengan menggunakan 3 medium cair yaitu malt extract broth (MEB), glucose peptone yeast (GPY), dan minimal fungal media (MFM), serta waktu kultivasi, yaitu 2, 4, 6, 8, and 10 minggu. Hasil penelitian memperlihatkan bahwa $30 \mu \mathrm{g} / \mathrm{ml}$ ekstrak kasar MFW 23-08 yang dikultivasi dalam MFM selama 2 minggu mampu menghambat $87 \%$ pertumbuhan sel kanker payudara (T47D). Ekstrak kasar MFW 23-08 yang dikultivasi pada MEB selama 6 minggu, pada konsentrasi $100 \mu \mathrm{g} / \mathrm{ml}$, mampu menghambat radikal bebas $56 \%$. Namun demikian, ekstrak yang diproduksi pada media MFM, pada konsentrasi 50 and $100 \mathrm{\mu g} / \mathrm{ml}$ tidak mampu menghambat pertumbuhan Escherichia coli dan Staphylococcus aureus. Identifikasi molekuler menggunakan primer ITS1-ITS4 memperlihatkan bahwa kapang MFW 23-08 memiliki kemiripan sebesar 99\% dengan Penicillium citrinum, P. griseofolvum and Penicillium sp.
\end{abstract}

Kata Kunci: bioaktif, kapang, spons, 'MFW 23-08, sel kanker payudara

\section{INTRODUCTION}

Terrestrial microbes have been well known as bioactive compound sources since decades ago and more than 120 important drugs isolates from microbes such as penicillin, siclosporin $\mathrm{A}$, and adriamiacin, have been commercialized. Marine microbes started to be explored and studied when Brotzu in 1951 has 
succesfully isolated cephalosporins $\mathrm{C}$ and $\mathrm{P} 1$ antibiotic from fungi Cephalosporium (Burton \& Abraham 1951 in Kelecom, 2002). Among microbes, marine fungi is subjected for bioprospecting since terrestrial microbes were stagnant in producing new active chemicals for drug discovery, and has been intensively studied in 1998. Marine fungi is well known as significant sources for bioactive compounds as shown by 272 new chemicals isolated from them. Of these, 75 were considered active and among them, 25 bioactive compounds were isolated from fungi associated with sponges (Neumann, 2008), and predicted by Bugni \& Ireland (2004) that more new bioactive compounds will be produced from fungi associated with sponges.

Exploration on fungi associated with sponges from Lombok straits, has found a marine fungi identified as Exserohilum rostratum. This fungi has been proven to be active against cancer cell line of MCF-7 but not against $\mathrm{H} 460$ and SF 268 cells (Chasanah et al., 2009). Anticancer compound from fungi Aspergillus ustus extract has been reported by Pratitis et al (2010), while extract the same bioactivity from fungi MFW 01-08, isolated from ascidian Aplidium longithorax, has been reported by Nursid et al. (2010). Previous work on the screening on fungi associated with marine sponge from Wakatobi waters showed that MFW 2308 has been proven to be one of the potential fungi which was active against HeLa cell line and contained potential antioxidant (Pratitis et al., 2009). The objective of this research is to identify the MFW 2308 fungi isolate and optimize the cultivation condition of MFW 23-08 to maximally produce the bioactive compounds.

\section{MATERIALS AND METHODS}

\section{Isolate}

Isolate of MFW 23-08 was obtained from sponge harvested from Wakatobi waters, which was preserved as a glycerol stock in $-80{ }^{\circ} \mathrm{C}$. The isolate was refreshed by plating it using MEB solid medium.

\section{Identification of The Fungi}

The fungi was identified through molecular taxonomy. Microbial DNA was extracted by scrapping mycelia (grown at solid medium) using a Power Plant DNA isolation kit (MO BI O Lab., Inc.). The 18S-rDNA gene primer and the Internal Transcribed Spacer (ITS) region of ITS1/ITS4 primer were used for DNA amplification. Negative results were obtained with the $16 S$ rDNA primer used in this study. PCR amplification was performed using Mastercycler gradient 5331 (Perkin Elmer Co.). PCR mixtures (per $50 \mu \mathrm{l}$ of reaction mixture) contained $5 \mu$ l of $10 \times$ RedTaq PCR buffer ( 15 $\mathrm{mM} \mathrm{Mg}^{2+}$-Sigma, St. Louis, Missouri), $8 \mu$ of dNTP's, $8 \mu \mathrm{l}$ of primer, $0.2 \mu \mathrm{l}(1.5 \mathrm{U})$ of Taq polymerase (Sigma RedTaq) and DNA template. PCR amplifications were conducted employing a basic format. Initial denaturation at $95^{\circ} \mathrm{C}$ for $3 \mathrm{~min}, 30$ cycles of denaturation at $94^{\circ} \mathrm{C}$ for $30 \mathrm{~s}$, annealing at variable temperatures for $30 \mathrm{~s}$, elongation at $72^{\circ} \mathrm{C}$ for variable times, final elongation at $72^{\circ} \mathrm{C}$ for $2 \mathrm{~min}$. Sequencing of the near-complete internal transcribed spacer (ITS) region of fungi isolates was conducted at the Macrogen Laboratory, Seoul, South Korea.

\section{Cultivation of Fungi in Liquid Media}

Cultivation was conducted using 3 liquid media, i.e MFM $(0.02 \%$ yeast extract, $0.1 \%$ soluble starch $)$, MEB (0.3\% malt extract, $0.3 \%$ yeast extract, $0.5 \%$ pepton), and GPY $(0.1 \%$ glucosa, $0.05 \%$ soybean pepton, $0.01 \%$ yeast extract). All of them were solubilized using artificial seawater (ASW). Starter was prepared using $5 \mathrm{~d}$ old fungi in slant agar culture, by scrubbing the mycelium and spore to liquid media culture. Cultivation was done in $100 \mathrm{ml}$ of $1 \mathrm{~L}$ cultivation bottles, in static condition, room temperature $\left(25^{\circ} \mathrm{C}\right)$, during $10 \mathrm{wk}$. Sampling was conducted every $2 \mathrm{wk}$.

\section{Determination of Fungi Biomass}

Biomass as a result of mycelium growth during cultivation was determined every 2 wk by measuring the dry weight of mycelium formed. The mycelium was separated from the extract by filtering the extract using filter paper Whatman no. 41 , and then dried using dry oven $\left(80^{\circ} \mathrm{C}\right)$.

\section{Extraction of The Metabolites}

Extraction was conducted by the addition of ethyl acetate $(1: 1)$ to culture medium, then mixed vigorously for 2-3 $\mathrm{h}$, sonicated for $25 \mathrm{~min}$, and finally ethyl acetate fraction was separated. Extract in ethyl acetate was then concentrated using rotary evaporator.

\section{Bioactivity Assay}

\section{In vitro cytotoxicity assay against T47D}

Anticancer potency of the extract was analyzed using MTT (3-[4,5-dimetilthiazol-2yl]-2,5-difenil tetrazolium bromida) method according to Zachary (2003). T47D cell was cultured in RPMI 1640 medium containing 10\% Fetal Bovine Serum (FBS), 1\% fungizone and $2 \%$ Penicillin-Streptomycin. Crude extract of the fungi in the concentration of $30 \mathrm{ppm}$ was used for the test in triplicates. Blanks solution prepared as follows: 1$)$ cell $(100 \mu \mathrm{l}$ cell $+100 \mu$ l media), 2) media (200 $\mu$ l media), 3) sample (100 $\mu$ l crude 

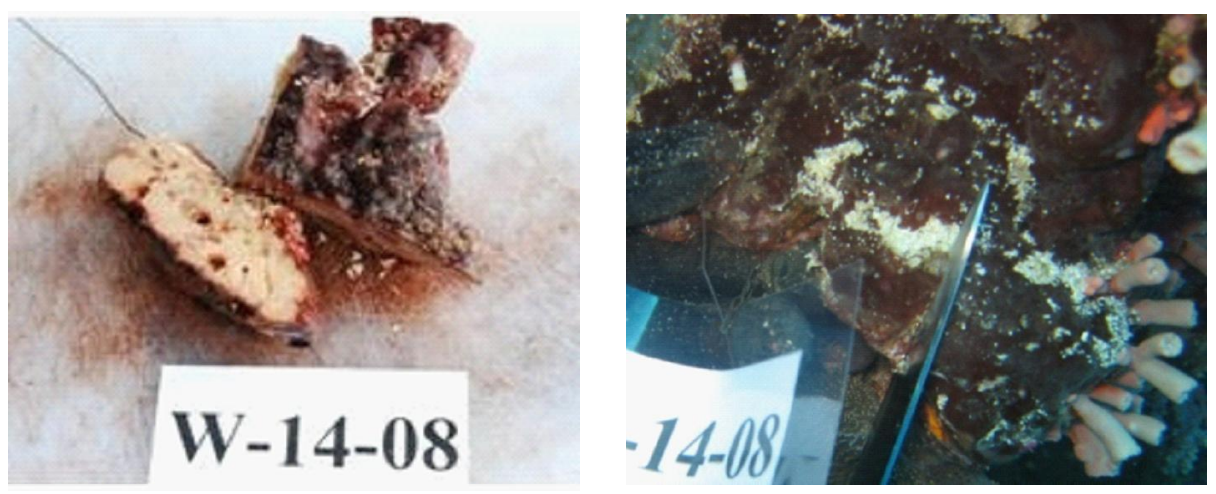

Figure 1. Host of MFW 23-08 fungi isolate.

extract $+100 \mu \mathrm{l}$ media) and 4) DMSO $(100 \mu$ l cell + $100 \mu \mathrm{l}$ DMSO). A $100 \mu \mathrm{l}$ of fungi crude extract was added to $10^{5}$ tumor cell T47D $(100 \mu \mathrm{l})$ which was previously cultivated in microplate for $24 \mathrm{~h}$, and then incubated for $48 \mathrm{~h}$ in $\mathrm{CO}_{2}$ incubator. At the end of incubation, $10 \mu \mathrm{l}$ of MTT was added to each well of the plates and incubated again for $4 \mathrm{~h}$ in $\mathrm{CO}_{2}$ incubator. The reaction of MTT was stopped by addition of $10 \%$ sodium dodecyl sulfate (SDS), and then incubated for $12 \mathrm{~h}$ in dark room, at room temperature. Absorbance was measured using DYNEX Spectrophotometer microplate reader at $570 \mathrm{~nm}$.

\section{Antioxidant activity}

Assessment on antioxidant activity was conducted by DPPH (2,2-diphenyl-1-picrylhydrazyl) method according to Li et al. (2006). Methanol extract of fungi was prepared in concentration of $100 \mathrm{ppm}$, and $160 \mu \mathrm{l}$ of the extract was plated in to the wells and added with $40 \mu \mathrm{l}$ DPPH solution. For control, $40 \mu \mathrm{l}$ metanol was added to $160 \mu \mathrm{l}$ of each extract tested. Negative control was made by adding $40 \mu \mathrm{l}$ DPPH into $160 \mu \mathrm{l}$ metanol, while the blank was prepared by using 200 $\mu \mathrm{l}$ metanol. Positive control used was ascorbic acid. Plates were incubated at room temperature for $30 \mathrm{~min}$, and absorbance was read using Dynex microplate reader at $510 \mathrm{~nm}$.

\section{Antibacterial activity}

Antibacterial test was done using modified disk diffusion method Kirby-Bauer (Wang, 2007). The bacteria (Staphylococcus aureus and Escherichia coli) were grown in Nutrient Broth medium for $18 \mathrm{~h}$, and prepared for testing when they have reached the optical density (OD) of $0.5-0.6$ or equivalent with $10^{6}-10^{8} \mathrm{cfu} /$ $\mathrm{ml}$. Nutrient agar medium was distributed in $20 \mathrm{ml}$ and autoclaved at $121^{\circ} \mathrm{C}$ for $15 \mathrm{~min}$, then cooled to $45^{\circ} \mathrm{C}$. The bacteria was seeded into medium and then pour into sterilized petri dishes. A paper disk containing $20 \mu \mathrm{l}$ of marine fungi extract was placed onto the surface of agar containing the bacteria. Concentrations of the extract used were 50 and 100 $\mathrm{ppm}$, with control positive used was chloramphenicol at the same concentration. Plates were incubated for $20-24 \mathrm{~h}$ at $37^{\circ} \mathrm{C}$. Antibacterial activity was indicated by a the clear formation of zone surrounding the paper disks. All the test were done in duplicates.

\section{RESULTS AND DISCUSSION}

MFW 23-08 fungi was isolated from sponge $W$ 14-08 (Fig. 1), harvested at Wakatobi waters, Sulawesi Tenggara. Using ITS 1 and ITS 4, and Blast analysis, it showed that MFW 23-08 fungi isolate have similarity to Penicillium species, i.e Penicillium griseofulvum (99\%), Penicillium citrinum (99\%) and Penicillium sp. $(99 \%)$. Phylogenetic tree of the isolate is shown in Figure 2, indicating that among Penicillium, MFW 2308 was likely closer to Penicillium citrinum and $P$. griseofulvum.

The Penicillium was known as terrestrial fungi, however they may have different physiological characteristics and posses different bioactivity as a result of their adaptation to the marine environment. Some marine fungi such as Aspergillus and Penicillium are identified mycologically as terestrial fungi but it was reported that they can adapt to marine environment, grew abundantly and produce better secondary metabolites with increasing seawater in their medium cultivation, being the most optimal at concentration of $4 \%$ sodium chloride (Masuma et al. , 2001).

When cultivated at 3 different media, isolate MFW 23-08 was optimally grown, expressed as dry weight of mycelium, during 8 wk. Growth curve of MFW 2308 (Fig. 3) showed that the isolate have similar growth curve pattern when cultivated at 3 different media, being the highest when the isolate was cultivated at MEB, followed by GPY and MFM. Using the MEB medium, cultivation during 8 wk produced the highest crude 


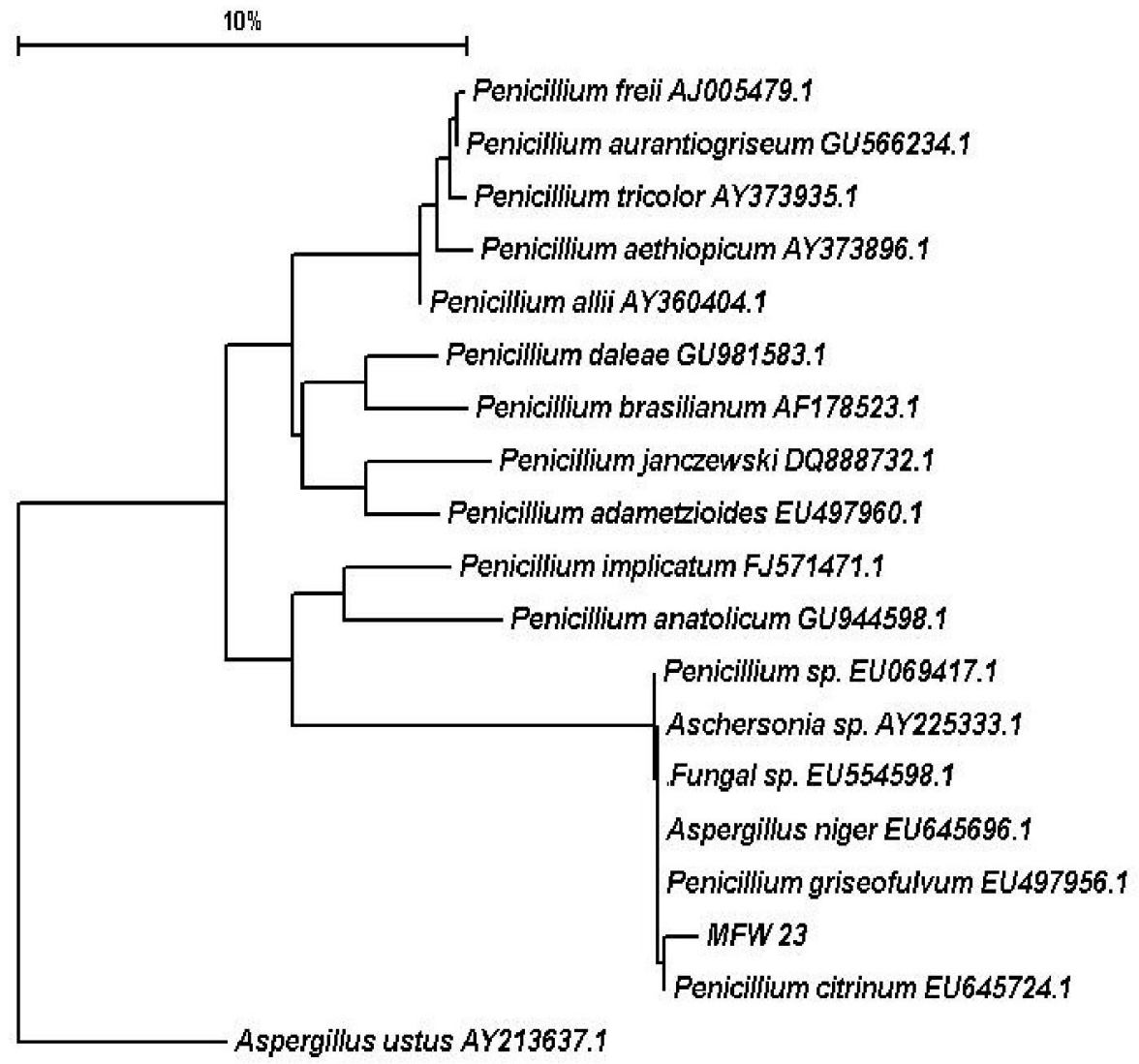

Figure 2. Phylogenetic tree of MFW 23-08 isolate

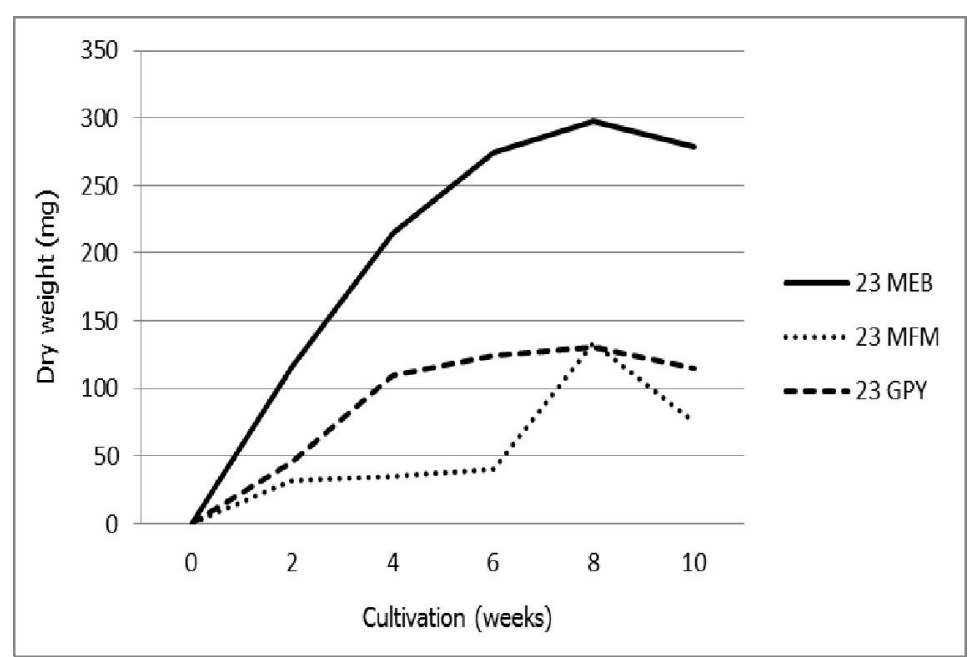

Figure 3. Growth curve of MFW 23-08 isolate.

extract yield, but became lower after $10 \mathrm{wk}$ (Fig. 4). This shown that MEB can support a good fungi growth expressed by biomass development while MFM and GPY, were considered as poor medium, they are not as good as MEB in supporting the growth of the fungi.

Medium give an important impact on the growth development of fungi eventhough growth of fungi always has similar model of growth curve (Cormican \& Pfaller,
1996; Meletiadis et al., 2001). This MFW 23-08 did not follow S-shape growth curve, representing lag, logaritmic or exponential, decline, static and lysis phases, but it is likely follow Meletiadis et al. (2001) who divides fungi growth curve into 5 distinct phases, i.e the lag phase, the first transition period, the log phase, the second transition period and the stationary phase. However, the transition state was likely not well appeared in this experiment, meaning that the 


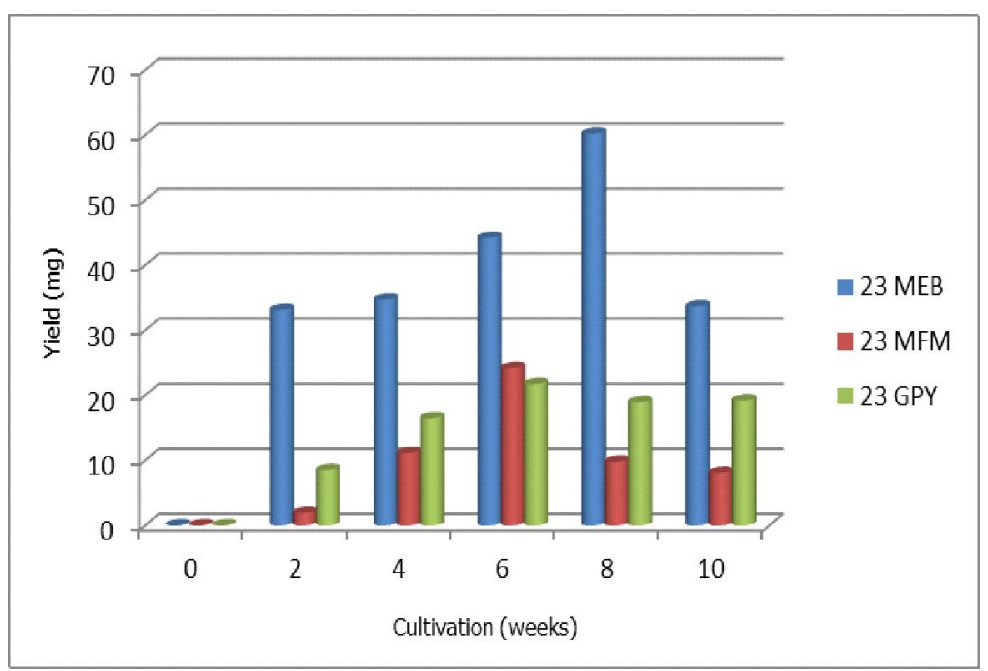

Figure 4. Yield of MFW 23-08 fungi extract at 3 different mediums and cultivation time of $10 \mathrm{wk}$.

isolate might better adjusted to the new cultivation condition.

Figure 5 showed MFW 23-08 crude extract activity against T47D cell. The highest anticancer activity of the MFW 23-08 crude extract was obtained on the 10 wk of cultivation, with the highest value of those produced at GPY, MFM and MEB media, respectively. It means that the medium needed for biomass development was different for those used for bioactivity production. Using extract concentration of $30 \mu \mathrm{g} / \mathrm{ml}$, $69 \%$ of T47D cell was died, indicated by less formation of formazan crystal. The formation of formazan crystal was resulted from the reaction of succinate dehydrogenase of the mitochondrial live cell with tetrazolium salt in MTT reaction. Application of the extract also caused change of cell morphology (Fig. 6).

Antioxidant activity test of MFW 23-08 crude extract showed that the fungi cultivated at MEB for 4 wk produced the highest free radicals inhibition through DPPH method, i.e 70\% (Fig. 7). At the same concentration, ascorbic acid (positive control) inhibited $85 \%$ of free radicals. Production of anticancer by Aspergillus ustus was reported to be 2 wk in MFM media, while when cultivated at MEB for 6 wk, the fungi produced antioxidant (Pratitis et al., 2010). Nursid et al. (2010) also reported the potency of fungi MFW 01-08 to produce anticancer when cultivated at MEB media for $5 \mathrm{wk}$. This fungi was isolated from Ascidia Aplidium longithorax from Wakatobi waters.

Fungi are well known as a producer of either deleteterious compounds such as mycotoxin or beneficial/advantageous compounds such as antibiotics and antitumor. The MFW 23-08 crude extract showed cytotoxic activity against T47D cell. The highest anticancer activity of the MFW 23-08 crude extract was obtained on the cultivation of $10 \mathrm{wk}$ while for antioxidant activity was 4 wk. However, Figure 7 showed that, it was likely that there are 2 peaks of

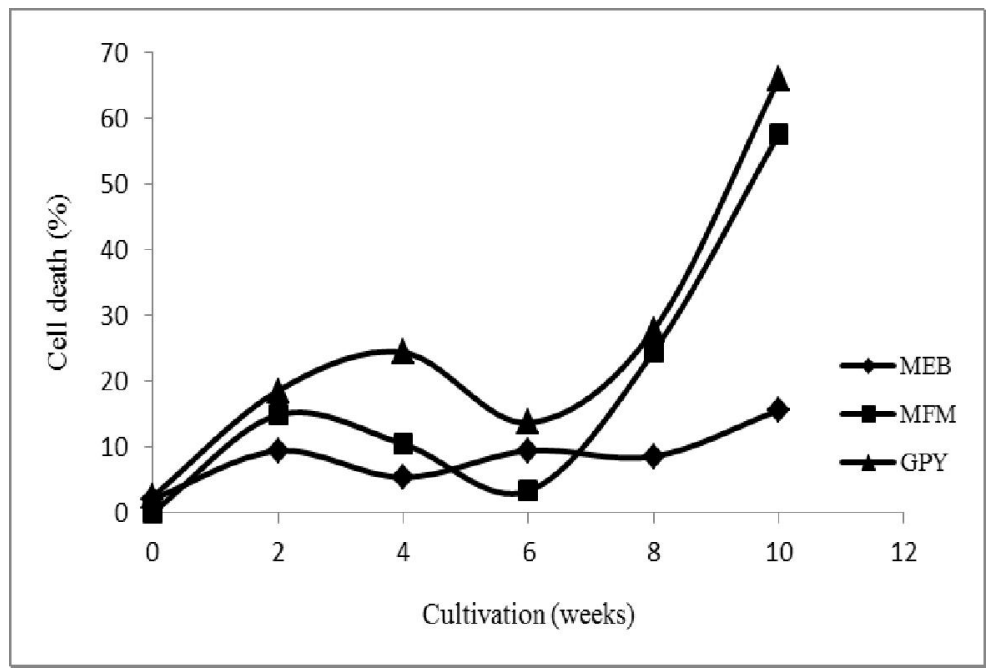

Figure 5. Antitumor activity of MFW $23-08$ crude extract $(30 \mu \mathrm{g} / \mathrm{ml})$. 

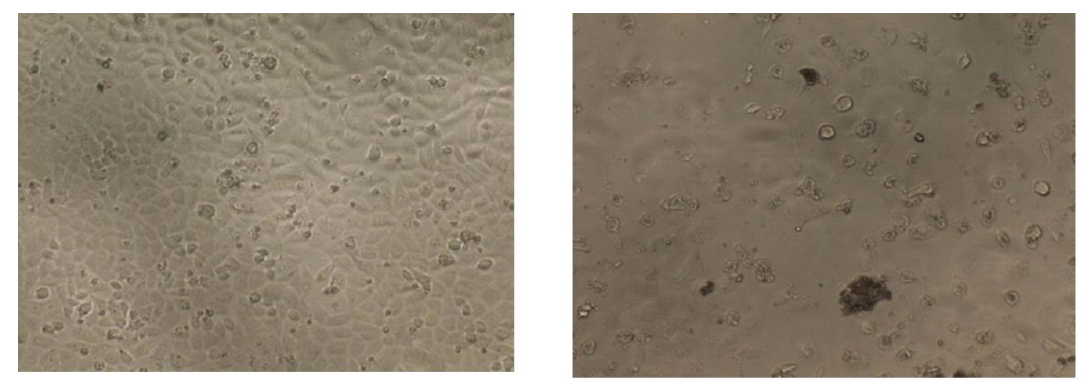

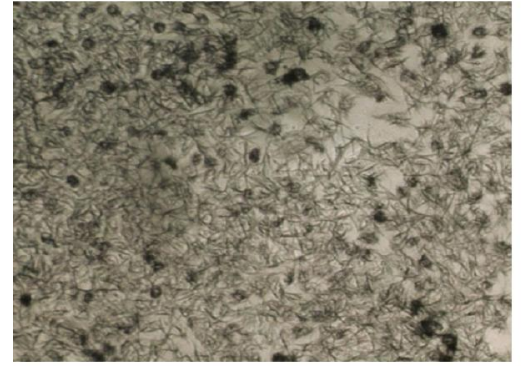

(c)

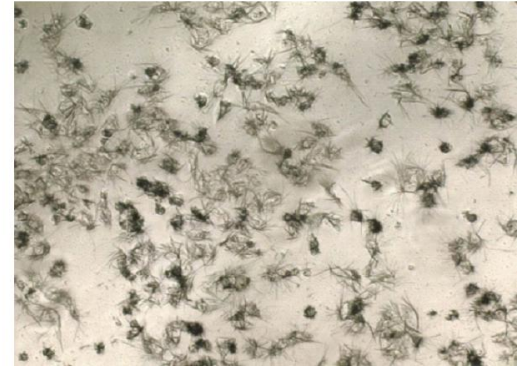

(d)

Figure 6. Morphology of T47D cell in antitumor test plates; (a) control cell, (b) cell treated with fungi extract, (c) formazan in control cell, and (d) formazan cells treated with fungi extract.

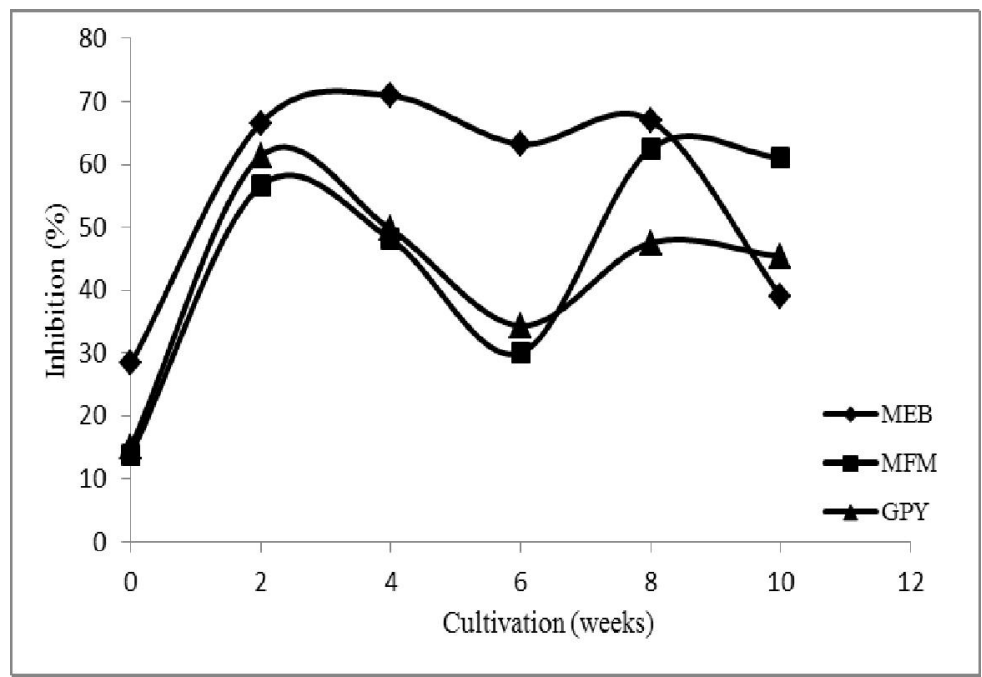

Figure 7. Antioxidant activity as percentage of DPPH inhibition by MFW 23-08 crude extract cultivated at 3 different medialus.

antioxidant activity by all crude extract tested. Calvo et al. (2002) reported that some secondary metabolites substances such as antioxidant was reported to be produced in relation to sporulation of the fungi. Some have function as virulence factor or for the spore to be survived, some are reported to stimulate sporulation and influence the development and fitness of the organism (Demain, 1986). The two peaks activity in Figure 7 might depict the sporulation process of the MFW 23-08 in medium before the medium was running out of nutrition needed. Arora \& Chandra (2010) reported that natural products are also often produced at the late of fungal development, and their biosynthesis was complex. In this study, the anticancer activity was reached at weeks 10 which was at declining growth phase of MFW 23-08. However, The MFW 23-08 crude extract cultivated at MFM medium showed no antibacterial activity against $S$. aureus and $E$. coli both at 50 and $100 \mu \mathrm{g} / \mathrm{ml}$ (Table 1). It means that the bioactive compounds formed during cultivation of MFW 23-08 at MFM medium, possesed selectivity. The extract selectively active for anticancer but not as antibacterial against $E$. coli and $S$. aureus.

Secondary metabolites produced by Penicillium extracts have been reported. Extracts obtained from the culture media of $P$. oxalicum and $P$. citrinum 
Table 1. Antibacterial activity of the MFW 23-08 crude extract cultivated at MFM medium

displayed antimycobacterial activity against Mycobacterium tuberculosis H37Rv and cytotoxic activity against $\mathrm{HCT}-8$ colon and $\mathrm{B} 16$ murine melanoma cancer cell lines ( $P$. oxalicum), as well as antifungal activity against Candida albicans ATCC 10231 (Pimenta et al., 2010). The Penicillium sp isolated from Brazilian soil was reported to have bioactivity against Candida albicans (minimum inhibitory concentration (MIC) $32 \mu \mathrm{g} / \mathrm{ml}$ ), Listeria monocytogenes and Bacillus cereus (MIC $64 \mu \mathrm{g} / \mathrm{ml}$ for both) (Petit et al., 2009). In this report, the MFW 23-08 which was closely identified as Penicillium griseofulvum and $P$. citrinum produced bioactive anticancer compound but not as antibacterial when cultivated at MFM medium at 10 wk of cultivation, and produced antioxidant when cultivated at MEB medium for $4 \mathrm{wk}$.

\section{CONCLUSION}

1. Isolate MFW $23-08$ had $99 \%$ similarity with $P$. citrinum, $P$. griseofulvum and Penicillium sp.

2. The isolate produced bioactive compound (anticancer) when cultivated at GPY $(100 \mathrm{ml})$ for 10 wk by retarding $69 \%$ of T47D at concentration of $30 \mu \mathrm{g} / \mathrm{ml}$

3. When cultivated at MEB medium (100 ml) for 4 $w k$, the isolate was able to produce bioactive (antioxidant) in which at concentration of $100 \mu \mathrm{g} /$ $\mathrm{ml}$ was able to hamper free radicals $(70 \%)$. At the extract concentration of 50 and $100 \mu \mathrm{g} / \mathrm{ml}$, they were unable to inhibit Escherichia coli and Staphylococcus aureus growth.

\section{ACKNOWLEDGEMENT}

The authors are gratefull to Gintung Patantis for his technical assistance.

\section{REFERENCES}

Arora, D.S. and Chandra, P. 2010. Assay of antioxidant potential of two Aspergillus isolates by different methods under various physio-chemical conditions. Braz. J. Microbiol. 41: 765-777.

Bugni, T. S. and Ireland, C. M. 2004. Marine-derived fungi: a chemically and biologically diverse group of microorganisms. Nat. Prod. Rep. 21:143-163.

Calvo, A. M., Wilson, R. A., Bok, J. W., and Keller, N. P. 2002. Relationship between secondary metabolism and fungal development. Microbiology and Molecular Biology Reviews. 3(2): 447-459.

Chasanah, E., Januar, H. I., Bourne, D., Liptrot, C., and Wright, A. D. 2009. Screening of anticancer activity of fungi derived from Indonesian marine sponges. Journal of Marine and Fisheries Postharvest and Biotechnology, special edition in conjunction with World Ocean Conference. 4: 1-8.

Cormican, M. G. and Pfaller, M. A. 1996. Standardization of antifungal susceptibility testing. J. of Antimicrobial Chemotherapy. 38: 561-578.

Demain, A. L. 1986. Regulation of secondary metabolism in fungi. J. Biology. $41: 765-777$.

Kelecom, A. 2002. Secondary metabolites from marine microorganisms. Anais da Academia Brasileira de Ciências. Annals of the Brazilian Academy of Sciences. 74(1): 151-170.

Li, Y., Li, X., Lee, U., Kang, J. S., Choi, H. D., and Son, B. W. 2006. A new radical scavenging anthracene glycoside, asperflavin ribofuranoside, and polyketides from a marine isolat of the fungus Microsporum. Chem. Pharm. Bull. 54(6): 882-883.

Masuma, R., Yamaguchi, Y., Noumi, M., Omura, S., and Namikoshi, M. 2001. Effect of sea water concentration on hyphal growth and antimicrobial metabolite production in marine fungi. Micoscience. 42: 455-459.

Meletiadis, J., Meis, J. F. G. M., Mouton, J. W., and Verweij, P. 2001. Analysis of growth characteristics of filamentous fungi in different nutrient media. J. of Clinical Microbiology. 3(2): 478-484.

Neumann, K. 2008. Marine-Derived Fungi : A Source for Structurally New and Bioactive Secondary 
Metabolites. Dissertation, Rheinischen FriedrichWilhelms-Universität Bonn. 153 pp.

Nursid, M., Pratitis, A., dan Chasanah, E. 2010. Kultivasi kapang MFW 01-08 yang diisolasi dari Ascidia Aplidium longithorax dan uji aktivitas sitotoksiknya terhadap sel kanker payudara T47D. J. Pascapanen dan Bioteknologi Kelautan dan Perikanan. 5(2): 103110.

Pratitis, A., Nursid, M., Januar, H. I., Mangunwardoyo, W., dan Chasanah, E. 2009. Isolasi dan uji bioaktivitas kapang yang berasosiasi dengan invertebrata laut asal perairan Wakatobi. Prosiding Seminar Nasional Riset Pasca Panen Perikanan. p. 1-9.

Pratitis A., Patantis G., Mangunwardoyo W., dan Chasanah E. 2010. Produksi senyawa bioaktif dari Aspergillus ustus MFW 26-08 yang berasosiasi dengan spons laut dalam berbagai media. $J$. Pascapanen dan Bioteknologi Kelautan dan Perikanan. 5(2): 93-102

Petit, P., Lucas, E. M. F., Abreu, L. M., Pfenning, L. H., and Takahashi, J. A. 2009. Novel antimicrobial secondary metabolites from a Penicillium sp. isolated from
Brazilian cerrado soil. Electronic Journal of Biotechnology. 12(4): 1-9.

Pimenta, E. F., Vita-Marques, A. M., Tininis, A., Seleghim, M. H., Sette, L. D., and Veloso, K. 2010. Use of Experimental Design for the optimization of the Production of New Secondary Metabolites by Two Penicillium Species. J of Nat. Product. 73:1821-1832 Ferreira, A. G., Williams, D. E., Patrick, B. O., Dalisay, D. S., Andersen, R. J., and Berlinck, R. G. S.. 2010. Use of experimental design for the optimization of the production of new secondary metabolites by two Penicillium Species. J. Nat. Prod. 73(11): 1821-1832.

Wang, Y., Zhou, P., Yu, J., Pan, X., Wang, P., Lan, W., and Tao, S. 2007. Antimicrobial effect of chitooligosaccharides produced by chitosanase from Pseudomonas CUY8. Asia Pac. J. Clin. Nutr. 16 (Suppl. 1):174-177.

Zachary, I. 2003. Determination of cell number. In Hughes, D. and Mehmet, $\mathrm{H}$ (eds). Cell Proliferation and Apoptosis. BIOS Scientific Publishers Ltd. Oxford. p.17-23. 